\title{
Effects of Physiological Status and Season on Blood Biochemical and Mineral Profile of Holstein Friesian Cross Bred Cattle
}

\author{
S. Usha ${ }^{1^{*}}$, T.K. Mohanty ${ }^{2}$ and P.Senthilkumar ${ }^{3}$ \\ ${ }^{1}$ Post Graduate Research Institute for Animal Sciences, TANUVAS, \\ Kattuppakkam, Chennai, India \\ ${ }^{2}$ Livestock Research Centre, National Dairy Research Institute, \\ Karnal-132001, Haryana, India \\ ${ }^{3}$ Mecheri Sheep Research Station, TANUVAS, Pottaneri, Salem District, Tamil Nadu, India \\ *Corresponding author
}

\begin{abstract}
A B S T R A C T
\end{abstract}

\begin{tabular}{|l|}
\hline Ke y w or d s \\
Minerals, \\
Biochemical \\
parameters, Cattle \\
\hline Article Info \\
\hline $\begin{array}{l}\text { Accepted: } \\
\text { 10 November } 2018 \\
\text { Available Online: } \\
10 \text { December } 2018\end{array}$ \\
\hline
\end{tabular}

The present study was conducted to elucidate the plasma mineral profile and serum biochemical parameters in Holstein Friesian cross bred cattle in different physiological stages and seasons. In each season and each physiological group 8 normal healthy animals randomly selected for blood sampling once in a month for minerals $\mathrm{Ca}, \mathrm{P}, \mathrm{Cu}, \mathrm{Zn}$ and $\mathrm{Mn}$; biochemical parameters glucose, BUN, and NEFA analysis. Blood plasma minerals and biochemical parameters were significantly $(\mathrm{P}<0.05)$ influenced by animal physiological conditions and season of the year. Whereas, season of the year did not influences the serum cholesterol level. Blood Plasma minerals estimated were within the normal range. However, mineral concentration were significantly $(\mathrm{P}<0.05)$ lower during winter. Similarly, glucose content was lower and the BUN and NEFA content were higher during winter compared to other season. Results indicate that the herd health status on metabolic and mineral profiles need to be evaluated regularly in different seasons to diagnose deficiencies and imbalances to achieve set targets in terms of production performance by adjusting feeding and mineral supplementation.

\section{Introduction}

The mineral level and biochemical parameters in animal body depends on large number of factors such as species, breed, age, sex, nutritional and health status, nutrients supplementation, seasonal and physiological variations (Khan et al., 2003; O'Brien et al., 2010; Gattani and Sareen, 2011). For maintaining better health and production animals need optimum concentrations of biochemical parameters and both macro and trace minerals. Recently, the essentiality of major and trace elements in animals for the maintenance of normal metabolic and production levels has been recognized (Khan et al., 2003). The responses of animals to environmental stress during different seasons have profound effects on some serum biochemical parameters (Mellau et al., 2007; Ganaie et al., 2013). Information regarding the effect of seasonal variation on this area for 
cross bred cattle is lacking hence, the present study was undertaken to investigate the possible influences of seasonal variations of serum biochemical (glucose, BUN, cholesterol and NEFA) and mineral status (Ca, P, Zn, Mn and $\mathrm{Cu}$ ) in cattle and the study has a potential to serve as the model for seasonal specific nutrient supplementation to animals in different seasons of year.

\section{Materials and Methods}

\section{Location and experimental animal}

Present study was conducted at Livestock Research Center, National Dairy Research Institute, Karnal, India on crossbred calves (Holstein Friesian $\times$ Tharparkar). Karnal is located on $29^{\circ} 42^{\prime} \mathrm{N}$ latitude and $72^{\circ} 02^{\prime} \mathrm{E}$ longitudes, with an altitude of 250 meters above the mean sea level in the bed of IndoGangetic alluvial plain. Depending on meteorological variables (Table 1) the whole duration of study was divided into four major seasons like rainy (July-September), autumn (October-November) winter (DecemberMarch) and summer (April-June). The study was carried out in Karan fries cattle grouped into six physiological classifications wise calf (aged below 3 months); Heifer (18- 22 months age); Heifer pregnant (6-8 months of pregnancy); Lactating cows (within 30 days after calving); High producing (>15kg/day); Low producing ( $<15 \mathrm{~kg} /$ day); Dry pregnant cows (60 days before calving). In each season, from each group 8 normal healthy animals randomly selected for blood sampling once in a month for blood minerals and biochemical analysis.

\section{Blood sampling, plasma metabolites and mineral estimation}

Blood samples from cattle belonging to different physiological states $(n=8)$ and from different seasons were collected by jugular venipuncture in heparinised vials, centrifuged at $3000 \mathrm{rpm}$ for $10 \mathrm{~min}$ to harvest the plasma which was then transferred to sterile, acidwashed vials, labelled and stored at $-40^{\circ} \mathrm{C}$ until transport to laboratory where the samples were stored at $-20^{\circ} \mathrm{C}$ for further analysis. Plasma metabolites; glucose (O-Toluidine end point method, Hultman, 1959), urea nitrogen (Rahmatullah and Boyde, 1980), cholesterol (ferric chloride-sulphuric acid method, Zlatkis et al., 1953), NEFA (modified copper soap extraction method, Shipe et al., 1980) were estimated. Plasma minerals $\mathrm{Ca}, \mathrm{Zn}, \mathrm{Cu}$ and Mn were estimated with the help of Atomic Absorption Spectrophotometer (Philips PU 9100X) whereas; Plasma inorganic phosphorus was estimated by standard method given by Fiske and Subbarow (1925).

\section{Statistical analysis}

The statistical analysis was done using Sigmaplot version 11.0 (Systat Software Inc., USA). Data sets were first tested for normality by Shapiro-Wilk's normality test and analysed by two way analysis of variance (ANOVA) with general linear model (GLM). All pairwise differences in mean were compared by Tukey post hoc test. Difference between means was considered statistically significant when $\mathrm{P} \leq 0.05$ and plasma metabolites and mineral concentrations were presented as mean $\pm \mathrm{SE}$.

\section{Results and Discussion}

The overall plasma mineral and biochemical parameters concentrations are shown in (Table 2 and 3). Mineral and biochemical parameters estimation for different physiological group at deferent season revealed significant $(\mathrm{P}<0.05)$ influence of animal physiological conditions and season in the present study except for plasma cholesterol level which is significantly influence by physiological condition not by season. 
The blood Ca level in different groups was within the normal range and above the critical level in the present study. However, near critical level of $\mathrm{Ca}$ was observed in the lactating cows which could be attributed to excessive secretion of $\mathrm{Ca}$ through milk (Asif et al., 1996 and Sen et al., 1989). The higher concentration of $\mathrm{Ca}$ in calf and heifer could be due to more efficient absorption of $\mathrm{Ca}$ in growing animals (Ricks, 1991). The observed $\mathrm{Ca}$ was significantly $(\mathrm{P}<0.05)$ low in winter followed by rainy, autumn and summer. This might be attributed to higher absorption efficiency during summer compared to winter (Khan, 2003). However, in the present study animals in all physiological stages were not in the risk of deficiency irrespective of seasons.

The study revealed adequate Phosphate irrespective of the physiological status and/ or season of the year with significantly $(\mathrm{P}<0.05)$ lower concentration in lactating and pregnant cows compared to young animals. The marked increase in phosphate secretion in milk may be the reason (Braithwait, 1983). The higher serum $\mathrm{P}$ in young animals because of the growth hormone results increased renal phosphate resorption (Kaneko et al., 1997). According to our result, there was significantly $(\mathrm{P}<0.05)$ lower level of $\mathrm{P}$ observed during winter followed by rainy, autumn and summer season. This finding was in accordance with the literature of Srivastava et al., (2000) and Sivaramanet al., (2002).

$\mathrm{Zn}$ concentration was adequate in all categories. However, pregnant animal showed higher concentration. These observations could be due to increased demand for $\mathrm{Zn}$ for fetus growth (Elnageeb and Abdelatif, 2010). The $\mathrm{Zn}$ concentration was significantly $(\mathrm{P}<0.05)$ influenced by season of the year. Animal shows significantly $(\mathrm{P}<0.05)$ lower level during winter compared to other season. In contrast, Khan et al., (2008) reported higher concentration in winter than summer. This discrepancy in result may be due to geographical area and soil of the study area.

$\mathrm{Cu}$ concentration observed was within the normal range. Higher $\mathrm{Cu}$ concentration was recorded in pregnant animals and calves. This might be due to increased demand and utilization of maternal $\mathrm{Cu}$ for development of fetal nervous systems (Elnageeb and Abdelatif, 2010). The observed $\mathrm{Cu}$ was significantly $(\mathrm{P}<0.05)$ lower in winter followed by rainy, autumn and summer. These observations were in agreement with the findings of other researchers (Pastrana et al., 1991).

The overall Mn level in KF cattle was $0.50 \pm 0.01$. The higher level was observed in heifer and lower level in calves. Similarly winter season sample shows lower level compared to other season.

The significant $(\mathrm{P}<0.05)$ higher level of blood glucose was observed in calves in all the season compare to other groups and the concentration of plasma glucose differs significantly $\mathrm{P}<0.05$ ) among the four seasons and also did not follow a similar pattern. It might be due to change or variation in the fodder other management effects. The blood glucose level gives an indicator of the energy status of an animal. In comparison to other groups growing heifers are under nourished as evident from glucose value, which could be one of the reasons for late maturity in our herd (24months). However; it has been established beyond doubt that nutritional status plays a major role in determining variations of the circulating glucose concentration levels (Campanile et al., 1997 and Montemurro et al., 1997). In lactating and pregnant cows the glucose values were higher compare to our findings of Sivaraman et al., (2002). Which could be due to increase in protein concentration in the ration of cows, whose protein requirements had already been met, 
triggers a more intense gluconeogenesis as depicted by higher glucose levels (Westwood et al., 2002). Similarly Dhoble et al., (2004) also reported increased blood glucose at the time of parturition and it could be due to storage of glucose during advanced pregnancy and the level remain maintained at the time of parturition but after calving the lactation starts and the concentration of glucose level declined up to one month in all the cows due to drainage through milk.

In lactating cows glucose levels were in agreement with findings of Rawat et al., (2006). A decrease in plasma glucose concentration towards calving in some dairy cows was found to be associated with low milk production in early lactation (Schwalam and Schuitz, 1976). The glucose concentration increased significantly with approaching parturition and minimum values observed early phase of lactation. These low concentrations could be attributed to the negative energy balance, which is more pronounced during early phase of lactation. In the present study high yielding crossbred cows presumably reflecting greater demands for glucose in the mammary glands. In heavy lactating animals the glucose is excreted out as lactose through milk leading to hypoglycemia, which body tries to compensate through gluconeogenesis leading to deficiency of oxaloacetate (Kaneko, 1997).
The overall mean BUN concentration was high as compared to that reported by Kaneko (1997). The rise in BUN level may denote imbalance of protein and energy levels in the diet. The lower level of BUN during winter season may also be because of nonavailability of leguminous fodder. The BUN level was higher in lactating cows than pregnant cattle agreement with the findings of Sivaraman et al., (2002). Shaffer et al., (1981) observed that the BUN level increased with increasing age. The BUN values of pregnant and lactating cows are agreement with findings of Aswal (2009).Increasing plasma BUN towards calving and early lactation is due to insufficient energy intake that would have leads to an increase deamination of amino acids resulting in the increase in urea concentration. A low level of BUN before calving has been reported by Hammond (1983).

Plasma urea concentrations were close to the normal ranges during summer. The significant seasonal variations were obtained on milk urea concentration in dairy cows (Dhali et al., 2006). They also observed that milk urea significantly associated with crude protein content of the forages than the concentrates. Higher BUN in winter indicates deficiency in energy as sufficient quantity of leguminous fodder with high RDP is supplied during this period.

Table.1 Meteorological variable during the study period

\begin{tabular}{|c|c|c|c|c|}
\hline \multirow[t]{2}{*}{ Seasons } & \multicolumn{4}{|c|}{ Meteorological variables (Mean \pm SE) } \\
\hline & $\begin{array}{c}\text { Temperature } \\
\left({ }^{\circ} \mathrm{C}\right)\end{array}$ & $\begin{array}{c}\text { Relative Humidity } \\
(\%)\end{array}$ & $\begin{array}{l}\text { Rain fall } \\
\text { (mm) }\end{array}$ & $\begin{array}{c}\text { Wind speed } \\
(\mathbf{k m} / \mathbf{h r})\end{array}$ \\
\hline Rainy & $29.28 \pm 2.27$ & $80.17 \pm 5.46$ & $140.90 \pm 27.59$ & $4.20 \pm 0.26$ \\
\hline Autumn & $22.57 \pm 4.51$ & $67.00 \pm 13.31$ & $7.60 \pm 6.6$ & $2.25 \pm 0.35$ \\
\hline Winter & $16.48 \pm 2.82$ & $71.12 \pm 8.21$ & $4.40 \pm 1.8$ & $3.32 \pm 0.33$ \\
\hline Summer & $29.02 \pm 3.24$ & $54.00 \pm 9.53$ & $62.13 \pm 42.37$ & $7.23 \pm 0.78$ \\
\hline
\end{tabular}


Table.2 Effect of physiological status and seasonal variation on blood plasma minerals in Holstein Friesian cross bred cattle

\begin{tabular}{|c|c|c|c|c|c|c|}
\hline \multirow[t]{2}{*}{ Parameter } & \multirow[t]{2}{*}{ Physiological Status } & \multicolumn{4}{|c|}{ Season } & \multirow[t]{2}{*}{ Overall } \\
\hline & & Rainy & Autumn & Winter & Summer & \\
\hline \multirow[t]{7}{*}{$\mathrm{Ca}(\mathrm{mg} / \mathrm{dl})$} & Calf & $12.78^{\mathrm{aE}} \pm 0.09$ & $12.88^{\mathrm{aC}} \pm 0.12$ & $11.7^{\mathrm{cD}} \pm 0.08$ & $12.59^{\mathrm{bD}} \pm 0.09$ & $12.39^{\mathrm{d}} \pm 0.07$ \\
\hline & Heifer & $11.28^{\mathrm{bD}} \pm 0.10$ & $11.33^{\mathrm{bC}} \pm 0.13$ & $11.09^{\mathrm{cC}} \pm 0.09$ & $11.66^{\mathrm{aC}} \pm 0.11$ & $11.32^{c} \pm 0.06$ \\
\hline & Heifer pregnant & $9.30^{\mathrm{bC}} \pm 0.27$ & $9.29^{\mathrm{bB}} \pm 0.03$ & $9.16^{\mathrm{cB}} \pm 0.02$ & $9.54^{\mathrm{aB}} \pm 0.03$ & $9.31^{\mathrm{b}} \pm 0.02$ \\
\hline & Lactating high yielder & $8.48^{\mathrm{cA}} \pm 0.05$ & $8.46^{\mathrm{cA}} \pm 0.06$ & $8.56^{\mathrm{bA}} \pm 0.04$ & $8.67^{\mathrm{aA}} \pm 0.05$ & $8.55^{\mathrm{a}} \pm 0.03$ \\
\hline & Lactating low yielder & $8.63^{\mathrm{bB}} \pm 0.05$ & $8.43^{\mathrm{dA}} \pm 0.06$ & $8.54^{\mathrm{cA}} \pm 0.04$ & $8.78^{\mathrm{aA}} \pm 0.05$ & $8.60^{\mathrm{a}} \pm 0.03$ \\
\hline & Dry pregnant cows & $9.33^{\mathrm{bc}} \pm 0.04$ & $9.28^{\mathrm{bB}} \pm 0.04$ & $9.18^{\mathrm{cB}} \pm 0.03$ & $9.47^{\mathrm{aB}} \pm 0.04$ & $9.31^{b} \pm 0.02$ \\
\hline & Overall & $9.97^{\mathrm{B}} \pm 0.13$ & $9.95^{\mathrm{B}} \pm 0.17$ & $9.70^{\mathrm{A}} \pm 0.09$ & $10.12^{\mathrm{C}} \pm 0.13$ & $9.91 \pm 0.06$ \\
\hline \multirow[t]{7}{*}{$\mathbf{P}(\mathrm{mg} / \mathrm{dl})$} & Calf & $6.62^{\mathrm{aD}} \pm 0.09$ & $6.67^{\mathrm{aC}} \pm 0.11$ & $4.21^{\mathrm{cA}} \pm 0.08$ & $6.27^{\mathrm{bC}} \pm 0.09$ & $5.74^{c} \pm 0.12$ \\
\hline & Heifer & $5.52^{\mathrm{bC}} \pm 0.09$ & $5.28^{\mathrm{cB}} \pm 0.11$ & $4.81^{\mathrm{dB}} \pm 0.08$ & $5.65^{\mathrm{aB}} \pm 0.09$ & $5.28^{\mathrm{b}} \pm 0.06$ \\
\hline & Heifer pregnant & $4.36^{\mathrm{bA}} \pm 0.16$ & $4.45^{\mathrm{bA}} \pm 0.20$ & $4.85^{\mathrm{aB}} \pm 0.14$ & $5.07^{\mathrm{aA}} \pm 0.16$ & $5.07^{\mathrm{a}} \pm 0.19$ \\
\hline & Lactating high yielder & $4.61^{\mathrm{bB}} \pm 0.07$ & $4.64^{\mathrm{bA}} \pm 0.08$ & $4.67^{\mathrm{bB}} \pm 0.06$ & $4.90^{\mathrm{aA}} \pm 0.07$ & $4.71^{\mathrm{a}} \pm 0.03$ \\
\hline & Lactating low yielder & $4.67^{\mathrm{cB}} \pm 0.06$ & $4.67^{\mathrm{cA}} \pm 0.08$ & $4.79^{\mathrm{bB}} \pm 0.05$ & $4.97^{\mathrm{aA}} \pm 0.06$ & $4.79^{\mathrm{a}} \pm 0.03$ \\
\hline & Dry pregnant cows & $4.67^{\mathrm{bB}} \pm 0.04$ & $4.68^{\mathrm{bA}} \pm 0.05$ & $4.73^{\mathrm{abB}} \pm 0.04$ & $4.75^{\mathrm{aA}} \pm 0.04$ & $4.72^{\mathrm{a}} \pm 0.02$ \\
\hline & Overall & $5.08^{\mathrm{B}} \pm 0.07$ & $5.06^{\mathrm{B}} \pm 0.09$ & $4.68^{\mathrm{A}} \pm 0.04$ & $5.27^{\mathrm{C}} \pm 0.06$ & $4.99 \pm 0.03$ \\
\hline \multirow[t]{4}{*}{$\mathrm{Zn}(\mathrm{ppm})$} & Calf & $1.52^{\mathrm{aC}} \pm 0.02$ & $1.50^{\mathrm{aB}} \pm 0.02$ & $1.17^{\mathrm{cC}} \pm 0.02$ & $1.41^{\mathrm{bB}} \pm 0.02$ & $1.37^{\mathrm{b}} \pm 0.02$ \\
\hline & Heifer & $1.47^{\mathrm{bB}} \pm 0.02$ & $1.47^{\mathrm{bB}} \pm 0.02$ & $1.24^{\mathrm{cD}} \pm 0.02$ & $1.51^{\mathrm{aC}} \pm 0.02$ & $1.40^{\mathrm{b}} \pm 0.01$ \\
\hline & Heifer pregnant & $1.81^{\mathrm{aD}} \pm 0.01$ & $1.81^{\mathrm{aC}} \pm 0.02$ & $1.24^{\mathrm{bB}} \pm 0.01$ & $1.80^{\mathrm{aD}} \pm 0.01$ & $1.80^{c} \pm 0.01$ \\
\hline & Lactating high yielder & $1.08^{\mathrm{aA}} \pm 0.02$ & $1.10^{\mathrm{aA}} \pm 0.02$ & $0.94^{\mathrm{bA}} \pm 0.01$ & $1.08^{\mathrm{aA}} \pm 0.02$ & $1.03^{\mathrm{a}} \pm 0.01$ \\
\hline
\end{tabular}




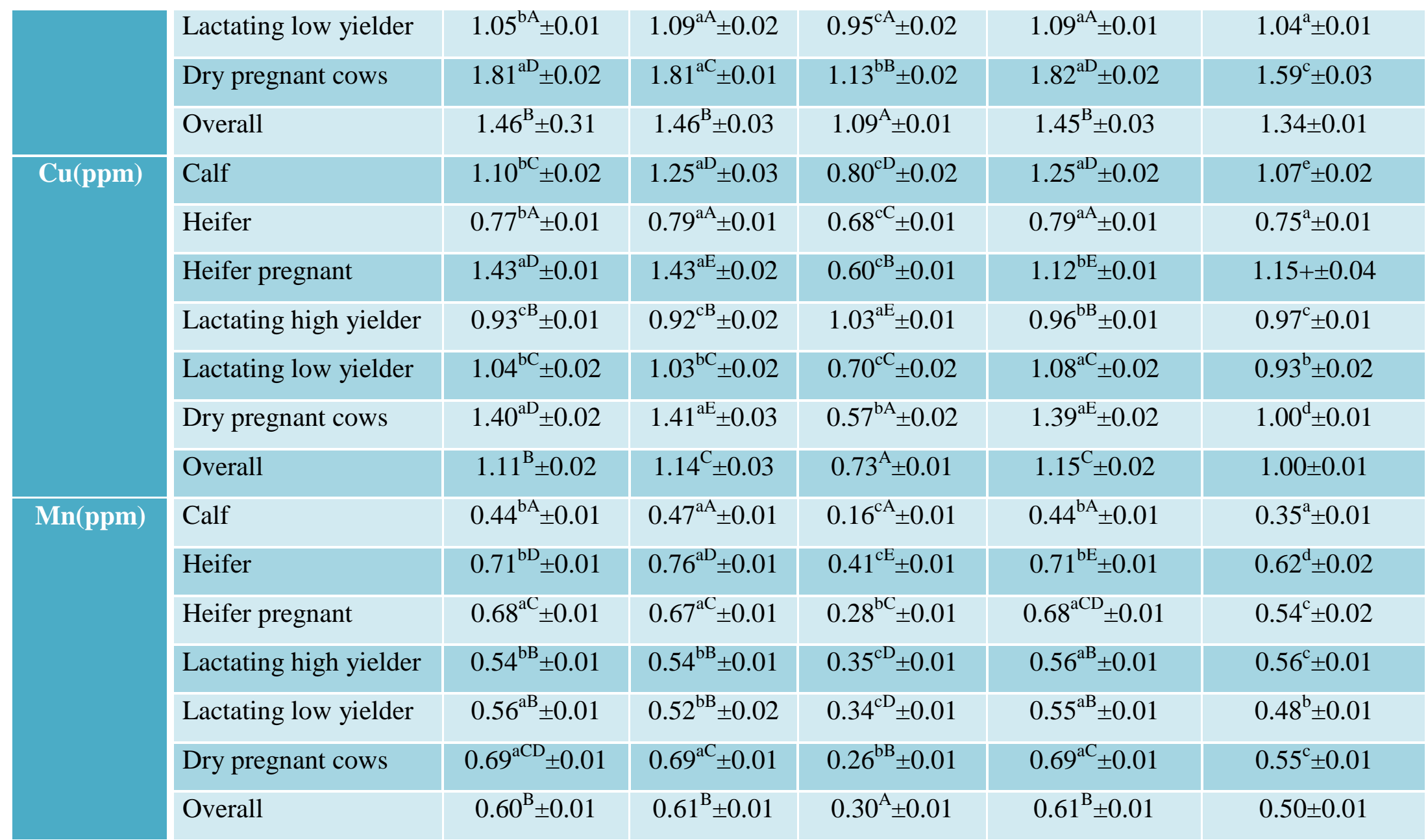

Means with different superscript in a row $(\mathrm{a}, \mathrm{b}, \mathrm{c}, \mathrm{d})$ and column $(\mathrm{A}, \mathrm{B}, \mathrm{C}, \mathrm{D}, \mathrm{E})$ differ significantly $(\mathrm{P}<0.05)$ 
Table.3 Effect of physiological status and seasonal variation on blood biochemical parameters in Holstein Friesian cross bred cattle

\begin{tabular}{|c|c|c|c|c|c|c|}
\hline \multirow[t]{2}{*}{ Parameter } & \multirow{2}{*}{$\begin{array}{c}\text { Physiological } \\
\text { Status }\end{array}$} & \multicolumn{4}{|c|}{ Season } & \multirow[t]{2}{*}{ Overall } \\
\hline & & Rainy & Autumn & Winter & Summer & \\
\hline \multirow[t]{7}{*}{ Glucose(mg/dl) } & Calf & $86.54^{\mathrm{aE}} \pm 1.02$ & $88.79^{\mathrm{aC}} \pm 1.25$ & $78.85^{\mathrm{dE}} \pm 0.89$ & $83.59^{\mathrm{cD}} \pm 1.02$ & $83.61^{d} \pm 0.63$ \\
\hline & Heifer & $66.34^{\mathrm{aC}} \pm 1.45$ & $56.72^{\mathrm{bA}} \pm 1.81$ & $55.04^{\mathrm{bC}} \pm 1.28$ & $65.70^{\mathrm{aB}} \pm 1.48$ & $60.81^{b} \pm 0.90$ \\
\hline & Heifer pregnant & $70.03^{\mathrm{bD}} \pm 0.74$ & $69.17^{\mathrm{bB}} \pm 0.90$ & $67.03^{\mathrm{cD}} \pm 0.64$ & $72.45^{\mathrm{aC}} \pm 0.74$ & $65.23^{c} \pm 0.08$ \\
\hline & $\begin{array}{l}\text { Lactating high } \\
\text { yielder }\end{array}$ & $61.98^{\mathrm{aB}} \pm 0.78$ & $56.90^{\mathrm{bA}} \pm 0.96$ & $48.25^{\mathrm{cA}} \pm 0.68$ & $57.12^{\mathrm{bA}} \pm 0.78$ & $65.29^{c} \pm 0.001$ \\
\hline & $\begin{array}{l}\text { Lactating low } \\
\text { yielder }\end{array}$ & $56.58^{\mathrm{bA}} \pm 0.46$ & $52.90^{\mathrm{cA}} \pm 0.57$ & $53.51^{\mathrm{cB}} \pm 0.40$ & $58.32^{\mathrm{aA}} \pm 0.46$ & $65.29^{c} \pm 0.001$ \\
\hline & $\begin{array}{l}\text { Dry pregnant } \\
\text { cows }\end{array}$ & $73.06^{\mathrm{aD}} \pm 0.99$ & $65.58^{\mathrm{bB}} \pm 1.22$ & $66.16^{\mathrm{bD}} \pm 0.86$ & $74.19^{\mathrm{aC}} \pm 0.99$ & $56.33^{\mathrm{a}} \pm 0.46$ \\
\hline & Overall & $68.15^{C} \pm 0.81$ & $65.71^{\mathrm{B}} \pm 1.63$ & $63.88^{\mathrm{A}} \pm 0.64$ & $67.25^{\mathrm{C}} \pm 0.74$ & $66.09 \pm 0.41$ \\
\hline \multirow[t]{7}{*}{ BUN(mg/dl) } & Calf & $30.70^{\mathrm{aC}} \pm 0.35$ & $30.95^{\mathrm{aB}} \pm 0.42$ & $28.85^{\mathrm{aA}} \pm 0.30$ & $23.15^{\mathrm{bB}} \pm 0.35$ & $28.24^{\mathrm{a}} \pm 0.36$ \\
\hline & Heifer & $28.85^{\mathrm{bA}} \pm 0.90$ & $23.47^{\mathrm{cA}} \pm 1.10$ & $30.83^{\mathrm{aC}} \pm 0.78$ & $23.46^{\mathrm{cB}} \pm 0.90$ & $27.27^{\mathrm{a}} \pm 0.56$ \\
\hline & Heifer pregnant & $31.82^{\mathrm{aC}} \pm 0.82$ & $31.38^{\mathrm{aB}} \pm 1.01$ & $30.15^{\mathrm{bAB}} \pm 0.07$ & $18.32^{\mathrm{cA}} \pm 0.82$ & $27.81^{\mathrm{a}} \pm 0.70$ \\
\hline & $\begin{array}{l}\text { Lactating high } \\
\text { yielder }\end{array}$ & $42.07^{\mathrm{bD}} \pm 0.42$ & $43.04^{\mathrm{aC}} \pm 0.52$ & $42.21^{\mathrm{bD}} \pm 0.36$ & $27.10^{\mathrm{cC}} \pm 0.42$ & $38.54^{\mathrm{b}} \pm 0.71$ \\
\hline & $\begin{array}{l}\text { Lactating low } \\
\text { yielder }\end{array}$ & $42.06^{\mathrm{aD}} \pm 0.45$ & $41.70^{\mathrm{aC}} \pm 0.55$ & $42.13^{\mathrm{aD}} \pm 0.39$ & $26.11^{\mathrm{bC}} \pm 0.45$ & $38.03^{\mathrm{b}} \pm 0.74$ \\
\hline & $\begin{array}{l}\text { Dry pregnant } \\
\text { cows }\end{array}$ & $31.33^{\mathrm{aC}} \pm 0.79$ & $29.87^{\mathrm{bB}} \pm 0.96$ & $29.65^{\mathrm{bAB}} \pm 0.68$ & $18.75^{\mathrm{cA}} \pm 0.79$ & $27.38^{\mathrm{a}} \pm 0.65$ \\
\hline & Overall & $34.47 \pm 0.54^{\mathrm{C}}$ & $33.40 \pm 0.79^{\mathrm{B}}$ & $33.97^{\mathrm{BC}} \pm 0.49$ & $22.82^{\mathrm{A}} \pm 0.32$ & $31.21 \pm 0.33$ \\
\hline \multirow[t]{2}{*}{ Cholesterol(mg/dl) } & Calf & $104.76^{\mathrm{aB}} \pm 2.34$ & $100.68^{\mathrm{bA}} \pm 2.87$ & $92.81^{\mathrm{cA}} \pm 2.03$ & $104.59^{\mathrm{aA}} \pm 2.34$ & $98.88^{\mathrm{a}} \pm 1.29$ \\
\hline & Heifer & $88.26^{\mathrm{dA}} \pm 5.08$ & $120.35^{\mathrm{bB}} \pm 6.21$ & $140.02^{\mathrm{aC}} \pm 4.40$ & $112.18^{\mathrm{cA}} \pm 5.08$ & $116.84^{\mathrm{b}} \pm 3.22$ \\
\hline
\end{tabular}


Int.J.Curr.Microbiol.App.Sci (2018) 7(12): 1122-1132

\begin{tabular}{|c|c|c|c|c|c|c|}
\hline & Heifer pregnant & $131.70^{\mathrm{aC}} \pm 2.01$ & $117.14^{\mathrm{dB}} \pm 0.46$ & $121.87^{\mathrm{cB}} \pm 1.74$ & $127.68^{\mathrm{bB}} \pm 2.01$ & $124.99^{c} \pm 1.12$ \\
\hline & $\begin{array}{l}\text { Lactating high } \\
\text { yielder }\end{array}$ & $208.88^{\mathrm{aD}} \pm 1.19$ & $202.53^{\mathrm{cD}} \pm 1.45$ & $206.75^{\mathrm{bD}} \pm 1.03$ & $206.52^{\mathrm{bC}} \pm 1.19$ & $206.25^{\mathrm{d}} \pm 0.65$ \\
\hline & $\begin{array}{l}\text { Lactating low } \\
\text { yielder }\end{array}$ & $207.14^{\mathrm{aD}} \pm 1.31$ & $204.67^{\mathrm{bD}} \pm 1.61$ & $206.65^{\mathrm{abD}} \pm 1.14$ & $205.90^{\mathrm{abC}_{ \pm 1.32}}$ & $205.90^{\mathrm{d}} \pm 1.83$ \\
\hline & $\begin{array}{l}\text { Dry pregnant } \\
\text { cows }\end{array}$ & $133.02^{\mathrm{aC}} \pm 2.13$ & $128.48^{\mathrm{bC}} \pm 2.60$ & $122.95^{\mathrm{cB}} \pm 1.84$ & $126.19^{\mathrm{cB}} \pm 2.13$ & $127.20^{c} \pm 1.12$ \\
\hline & Overall & $145.63 \pm 3.97$ & $145.64 \pm 4.40$ & $148.43 \pm 3.31$ & $147.18 \pm 3.81$ & $146.95 \pm 1.90$ \\
\hline \multirow[t]{7}{*}{ NEFA $(\mu \mathrm{mol} / \mathrm{l})$} & Calf & $195.15^{\mathrm{bA}} \pm 11.77$ & $160.27^{\mathrm{dA}} \pm 14.41$ & $178.38^{\mathrm{cA}} \pm 10.19$ & $250.61^{\mathrm{aD}} \pm 11.77$ & $222.61^{\mathrm{a}} \pm 9.61$ \\
\hline & Heifer & $259.23^{\mathrm{cB}} \pm 9.47$ & $205.14^{\mathrm{dB}} \pm 11.60$ & $334.31^{\mathrm{aC}} \pm 8.20$ & $275.37^{\mathrm{bB}} \pm 9.47$ & $279.28^{\mathrm{b}} \pm 6.56$ \\
\hline & Heifer pregnant & $291.27^{\mathrm{aC}} \pm 3.51$ & $272.38^{\mathrm{bC}} \pm 4.30$ & $295.36^{\mathrm{a}} \pm 3.04$ & $254.02^{\mathrm{cA}} \pm 3.51$ & $280.17^{\mathrm{b}} \pm 2.45$ \\
\hline & $\begin{array}{l}\text { Lactating high } \\
\text { yielder }\end{array}$ & $382.90^{\mathrm{bD}} \pm 3.97$ & $384.57^{\mathrm{abD}} \pm 4.86$ & $389.84^{\mathrm{aD}} \pm 3.44$ & $355.39^{\mathrm{cD}} \pm 3.97$ & $378.87^{c} \pm 2.67$ \\
\hline & $\begin{array}{l}\text { Lactating low } \\
\text { yielder }\end{array}$ & $390.81^{\mathrm{bD}} \pm 3.67$ & $387.28^{\mathrm{bD}} \pm 4.49$ & $404.62^{\mathrm{aD}} \pm 3.18$ & $338.87^{\mathrm{cC}} \pm 3.67$ & $381.84^{c} \pm 3.20$ \\
\hline & $\begin{array}{l}\text { Dry pregnant } \\
\text { cows }\end{array}$ & $275.78^{\mathrm{aBC}} \pm 3.18$ & $277.66^{\mathrm{aC}} \pm 3.90$ & $279.28^{\mathrm{aB}} \pm 2.75$ & $248.28^{\mathrm{bA}} \pm 3.18$ & $270.38^{\mathrm{b}} \pm 2.04$ \\
\hline & Overall & $299.19^{\mathrm{B}} \pm 6.70$ & $281.22^{\mathrm{A}} \pm 8.95$ & $313.63^{C} \pm 6.12$ & $303.76^{\mathrm{B}} \pm 4.11$ & $302.15 \pm 3.23$ \\
\hline
\end{tabular}

Means with different superscript in a row $(\mathrm{a}, \mathrm{b}, \mathrm{c}, \mathrm{d})$ and column $(\mathrm{A}, \mathrm{B}, \mathrm{C}, \mathrm{D}, \mathrm{E})$ differ significantly $(\mathrm{P}<0.05)$ 
Season of year did not influence the blood cholesterol level. The positive correlation of cholesterol with age of the cow is very important and the cholesterol level increased only up to 4 years of age and then decreased due to acclimatization to stress from lactation and gestation (Roussel et al., 1982). This continued increase of cholesterol with increasing age in present study is also reflected to get acclaimed to the stress of lactation and gestation.

The cholesterol level was higher in lactating stage than pregnant cows was in agreement with findings of Sivaraman et al., (2002) and dynamics of serum cholesterol values was similar to Singh et al., (2009) and Dhoble et al., (2004). In the present study heifers in autumn and winter season showed higher cholesterol level this could be due to negative energy balance as ad lib. Berseem was supplied during these periods.

In calf and heifer significant $(\mathrm{P}<0.05)$ difference was observed in all the seasons of the year. The NEFA levels in present experiment were found to increase significantly after calving. The results was in accordance with studies undertaken by Kokkonen et al., (2005) which reported that cows with higher BCS and greater BCS loss had increased concentration of NEFA and were particularly sensitive to oxidative stress.

The NEFA level of lactating and pregnant cows of present study was comparable to Aswal (2009). In lactating animal groups in our study with very high negative energy balance may be the reason for high incidence of production diseases in our herd. Drackley (2001) reported that normal values of NEFA for cows in positive energy balance were less than $200 \mu \mathrm{M}$. High yielding dairy cows remain in a state of negative energy balance during postpartum because the amount of energy required for maintenance of body tissue functions and milk production exceeds the amount of energy cows could consume.

In conclusion we found significant seasonal changes in mineral and biochemical changes in healthy animals. Our results proposes the metabolic and mineral profiles need to be evaluated regularly in different seasons to diagnose deficiencies and imbalances to achieve set targets in terms of production performance by adjusting feeding and mineral supplementation.

\section{Acknowledgement}

The authors are thankful to Director, National Dairy Research Institute (NDRI), Karnal and Dr. Shiv Prasad, in-charge Livestock Research Center, National Dairy Research Institute, Karnal for providing research facilities.

\section{Conflict of interest}

None

\section{References}

Asif, M., Rahman, Z. U., Arif, M., Haq, I. U. and Javed, I. 1996. Trace element and electrolyte concentrations in different physiological states of Sahiwal cattle. J. Islam. Acad. Sci., 9, 125-128.

Aswal, M. 2009. Changes in hematological parameters, milk cell counts and metabolic status of high yielding dairy cows during transition period.M.V.Sc Thesis Submitted to National Dairy Research Institute, Karnal, India.

Braithwaite, G. D. 1983. Calcium and Phosphorus requirements of the Ewe during pregnancy and lactation. Br. J. Nutr., 50, 711-722.

Campanile, G., Dipalo, R. and Angelo, A. D. 1997. Profile metaboliconel buffalo. Bubalus bubalis, 236-249.

Dhali, A., Mehla R. K., Sirohi, S. K., Mech, A. 
and Karunakaran, M. 2006. Monitoring feeding adequacy in dairy cows using milk urea and milk protein contents under farm conditions. Asian-Aust. J. Anim. Sci., 19, 1742-1748.

Dhoble, R. L., Mane, S. D., Sawale. A .G. and Ingawale, M. V. 2004. Variation in blood biochemical constituents during postpartum period in crossbred cows. Indian J. Anim. Re. Prod., 25, 14-16.

Drackley, J. K., Overton, T.R., Douglas, G.N. 2001. Adaptations of glucose and long chain fatty acid metabolism in liver of dairy cows during the periparturient period. J. Dairy Sci., 84, E100-E112.

Elnageeb, M. A. and Abdelatif, A. M. 2010. The mineral profile in Desert ewes (Ovisaries): Effects of pregnancy, lactation and dietary supplementation. American - Euras. J. Agric. Environ. Sci., 7, 18-30.

Fiske, C. H. and Subbarow, Y. 1925. The colorimetric determination of phosphorus. J Biol. Chem., 66, 375-400.

Ganaie, A. H., Ghasura, R. S., Mir, N. A., Bumla, N. A., Sankar, G. and Wani, S. A. 2013. Biochemical and Physiological Changes during Thermal Stress in Bovines: A Review Iranian J. Appl. Anim. Sci., 3, 423-430.

Gattani, A. and Sareen, M. 2011. Influence of age and season on thyroid activity and blood biochemical profile in magra rams under arid tropical environment. Indian J. Small Rumin., 17, 237-239.

Hammond, A. C. 1983. Use of blood urea nitrogen concentration as an indicator of protein status in cattle. Bovine Practitioner, 18, 114-118.

Hultman, E.1959. Raped specific method for determination of aldohexoses (aldosaccharides) in body fluids. Nature 103:108-109.

Kaneko, J. J. 1997. Carbohydrate metabolism and its diseases. Clinical Biochemistry of Domestic Animals. $4^{\text {th }}$ Ed, (Ed. Kaneko J W Harvy and M.L Bruss), Academic Press, New York. pp. 233-239.

Khan, Z. I., Ahmed, K., Ashraf, M., Valeem, E.
E. and Javed, I. 2008. A comparative study on mineral status of blood plasma of small ruminants and Pastures in Punjab, Pakistan. Pak. J. Bot. 41:67-72.

Khan, Z. I., Ashraf, M., Ashraf, M.Y., Rahman, Z. and Hussain, A. 2003. Mineral status of livestock (Goats and Sheep) based on soil, dietary components and animal tissue fluids in relation to seasonal changes and sampling periods in specific region of Pakistan. J. Anim. Vet, 2: 478495.

Kokkonen, T., Taponen, J., Anttila, T., SyrjalaQvist, L., Delavaud, C., Chilliard, Y., Tuori, M. and Tesfa, A. T. 2005. Effect of body fatness and glucogenic supplement on lipid and protein mobilization and plasma leptin in dairy cows. J. Dairy Sci., 88, 1114-1127.

Mellau, L. S. B., Lekule, L.S.B., Shem, F.P., Hayashida, M.N., Fujihara, T. 2007. Seasonal influence on mineral concentrations in dairy cows' blood and feed resources collected from Morogoro, Tanzania. J. Food. Agric. Environ., 5, 274-280.

Montemurro, N., Pacelli, C. and Borghese, A., 1997. Blood metabolites change in milking buffalo cows. Bubalus bubalis, 3, 69-78.

O'Brien M.D., Rhoads R.P., Sanders S.R., Duff G.C., Baumgard L.H. 2010. Metabolic adaptations to heat stress in growing cattle. Domestic Anim. Endocrinol., 38, 86-94.

Pastrana, R., McDowell, L. R., Conrad, J. H. and Wilkinson, N. S. 1991. Macromineral status of sheep in the Paramo region of Colombia. Small Rumin. Res., 5, 9-21.

Piccione, G., Messina, V., Marafioti, S. and Casella, S. 2012. Changes of some haematochemical parameters in dairy cows during late gestation, post partum,lactation and dry periods. Vet Med Zoot., 58, 59-64.

Piccione, G., Messina, V., Scianó, S., Assenza, A., Orefice, T., Vazzana I. and Zumbo, A. 2012. Annual changes of some 
metabolical parameters in dairy cows in the Mediterranean area. Vet Arhiv., 82, 229-238.

Rahmatullah, M. and Boyde, T.R.C. 1980. Improvement in the determination of urea diacetylmonoxime: Method with or without deproteinization. Clinica Chimica Acta, 107, 3-9.

Rawat, B., Nigam, R. and Jain. A. K. 2006. Metabolic profile in late pregnancy and early lactation in Haryana and crossbred cows. Indian Vet. J., 83, 795-797.

Roussel, J. O., Seybt, H. and Toups, G. 1982. Metabolic profile testing for Jersey cows in Louisiana: Reference values. Am. J. Vet. Res., 43, 1075-1077.

Schwalm, J. W. and Schultz, L. H. 1976. Relationship of insulin concentration to blood metabolites in the dairy cow. J. Dairy. Sci., 59, 255.

Sen, M. M., Ahmed, M. J. and Rahman, A. 1989. Effects of parturition and lactation on blood minerals and glucose status of dairy cattle. Bangladesh Veterinarian, 6, 10-13.

Shaffer, L., Roussel, J. D. and Koonce, K. L. 1981. Effect of age temperature, season and breed on blood characteristics of dairy cattle. J. Dairy Sci., 64, 62-70.

Shipe, W.F., Senyk, G.F., Fountain, K.B. 1980. Modified copper soap solvent extraction method for measuring free fatty acids in milk. Journal of Dairy Science, 63, 193198.

Singh, R. R., Dutt, T., Mandal, A. B. Joshi, H.
C. Pandey, H. N. and Singh, M. 2009. Effect of body condition score on blood metabolite and production performance in crossbred dairy cattle. Indian J. Anim. Sci., 79, 629-635.

Sivaraman, T., Shanmugasundaram, S., Arunachalam, S. and Sivakumar, T. 2003. Blood profile of Jersey crossbred cows under different physiological stages. Indian J. Anim. Res., 36, 144-117.

Sivaraman, T., Shanmugasundaram, S., Arunachalam, S. and Sivakumar, T. 2002. Blood profile constituents associated with production diseases in Jersey crossbred cows. Indian J. Anim. Sci., 73, 44- 47.

Smijsha, S. 2007. Effect of methods of feeding and individual housing on growth and health status of buffalo calves. M.V.Sc, Thesis submitted to National Dairy Research Institute, Karnal, India.

Spicer, L. J. and Francisco, C. C. 2003. Changes in plasma cholesterol concentration during early lactation in Holstein cows and its association with production variables. J. Dairy Sci., 73, 933-942.

Westwood, C. T., Lean, I. J. and Garvin, J. K. 2002. Factors influencing fertility of Holstein dairy cows: A multivariate description. J. Dairy Sci., 85, 3225-3237.

Zlatkis, A., Zak, B., Boyle, C.J., Mich, D.1953. A new method for determination of serum cholesterol. J. Lab. Clin. Med. 4:486-492.

\section{How to cite this article:}

Usha, S., T.K. Mohanty and Senthilkumar, P. 2018. Effects of Physiological Status and Season on Blood Biochemical and Mineral Profile of Holstein Friesian Cross Bred Cattle. Int.J.Curr.Microbiol.App.Sci. 7(12): 1122-1132. doi: https://doi.org/10.20546/ijcmas.2018.712.138 